\title{
Damage of wheat blast on the productivity and quality of seeds as a function of the initial inoculum in the field ${ }^{1}$
}

\author{
Delineide Pereira Gomes ${ }^{2 *}$, Valterley Soares Rocha ${ }^{3}$, \\ Olinto Liparini Pereira ${ }^{4}$, Moacil Alves de Souza ${ }^{3}$
}

\begin{abstract}
Information on damages caused by blast (Pyricularia oryzae) on wheat seed productivity is still scarce, especially studies on the effect of this on germination and vigor. This study aimed at evaluating blast damages on the productivity and quality of wheat seeds as a function of the initial inoculum in the field. Treatments were arranged in factorial 4x5: inoculations in four wheat genotypes (BRS 264, CD 116, CD 104 and VI 98053) with five doses of initial inoculum of P. oryzae (0, 5, 10, 20 and $30 \%$ of inoculated plants). The inoculation occurred in the stage of completely emerged spikes. The following determinations were made: incidence of blast in plants, dry matter mass of 100 plants, seed mass of 100 plants, productivity, germination, first count, germination speed index, dry mass of seedlings, hectolitric weight and incidence of $P$. oryzae in the seeds. There is a reduction in the productivity and physiological quality of the seeds of the genotypes due to the initial inoculum in the field. The transmission of $P$. oryzae occurs from the mother plant to the wheat seeds. In these genotypes, it is recommended not to use as seeds the ones coming from fields with blast incidence from $20 \%$ on in the plants, close to seed maturation.
\end{abstract}

Index terms: Triticum aestivum L., Pyricularia oryzae, germination, vigor, tolerance standards.

\section{Danos da brusone do trigo na produtividade e na qualidade das sementes em função do inóculo inicial no campo}

\begin{abstract}
RESUMO - Informações sobre danos causados pela brusone (Pyricularia oryzae) na produtividade de sementes de trigo ainda são escassas, sobretudo estudos sobre o efeito desta na germinação e no vigor. Objetivou-se avaliar os danos da brusone na produtividade e na qualidade de sementes de trigo em função do inóculo inicial no campo. Os tratamentos foram arranjados em fatorial 4x5: inoculações em quatro genótipos de trigo (BRS 264, CD 116, CD 104 e VI 98053) com cinco doses de inóculo inicial de P. oryzae (0, 5, 10, 20 e 30\% de plantas inoculadas). A inoculação ocorreu na fase de espigas completamente emergidas. Foram realizadas as seguintes determinações: incidência de brusone nas plantas, massa da matéria seca de 100 plantas, massa de sementes de 100 plantas, produtividade, germinação, primeira contagem, IVG, massa seca de plântulas, peso hectolítrico e incidência de P. oryzae nas sementes. Há redução da produtividade e da qualidade fisiológica das sementes dos genótipos em função do inóculo inicial no campo. Ocorre a transmissão de $P$. oryzae da planta-mãe para sementes de trigo. Nesses genótipos, recomenda-se não utilizar como sementes, aquelas provenientes de campos de produção com incidência de brusone a partir de $20 \%$ nas plantas, próximo à maturação das sementes.
\end{abstract}

Termos para indexação: Triticum aestivum L., Pyricularia oryzae, germinação, vigor, padrões de tolerância.

\section{Introduction}

The cultivation of wheat in Brazil comprises the South, Southeast and Midwest regions, and in the last decades, the tropical regions of the country presented a great potential, with very promising results (Cargnin et al., 2009; Oliveira et al., 2011; Coelho et al., 2016). However, wheat production in Central Brazil has suffered significant losses caused by blast (Pyricularia oryzae

\footnotetext{
${ }^{1}$ Submitted on 11/27/2016. Accepted for publication on 01/27/2017. ${ }^{2}$ Instituto Federal do Maranhão, IFMA, 65095-460 - São Luis, MA, Brasil. ${ }^{3}$ Departmento de Fitotecnia, UFV, 36570-900 - Viçosa, MG, Brasil.
}

Cavara), the latter becoming a limiting disease for the wheat expansion in this region (Goulart et al., 2007; Torres et al., 2009; Maciel et al., 2013; Rocha et al., 2014; Coelho et al., 2016).

Control measures for blast are still unsatisfactory, which characterizes it as difficult to control (Cruz et al., 2010; 2011; Rocha et al., 2014; Coelho et al., 2016). The use of resistance sources constitutes an important alternative, as a function of the low efficiency of the currently used fungicides (Cruz et

${ }^{4}$ Departamento de Fitopatologia, UFV, 36570-900 - Viçosa, MG, Brasil. *Corresponding author<delineide.gomes@ifma.edu.br> 
al., 2010; 2011; Silva et al., 2015).

The blast has shown high potential to cause reductions in wheat productivity in the tropical regions of the country. In Mato Grosso do Sul, Brazil, there is a record of losses in productivity of up to $74 \%$ (Goulart et al., 2007). In Minas Gerais, Brazil, fourteen wheat genotypes had a reduction in productivity as a function of the incidence of blast in two different sowing periods (Coelho et al., 2016). Researches claim that losses in wheat production caused by blast may vary and may reach up to $100 \%$ (Goulart et al., 1990; Goulart et al., 1992; Saharan et al., 2016).

In this context, several aspects of blast must be investigated, including the role of the seed in the pathogen dispersal (Goulart et al., 1995). In addition to the wind, the conidia of the fungus can also be efficiently dispersed through the seeds (Urashima et al., 2007; Debona et al., 2016). Infected wheat seeds may not have symptoms and they may constitute a source of primary inoculum of the disease in the field, generating epidemics by providing initial inoculum to new areas (Coelho et al., 2016), including for the fields of seed production, with serious consequences. Seed planting with $P$. oryzae was the probable cause for the dissemination of the fungus in wheat from Paraná to Mato Grosso do Sul (Urashima et al., 2007; Silva et al., 2009); and in triticale from Paraná to São Paulo (Medina et al., 2009). Furthermore, with regard to seed quality, the presence of the pathogen may be related to the low germination and low vigor. Studies on the effect of $P$. oryzae on germination are not well known (Urashima et al., 2009).

Since field inspections are performed based on the incidence of the disease in plants, the relation between the presence of blast in the field and the incidence of the pathogen in the seeds should be investigated (Cornélio et al., 2000). For this end, the establishment of tolerance standards of the pathogen in the field and in the seeds is essential. For P. oryzae, according to Machado (1994), in programs for certification of wheat seeds, the incidence of $5 \%$ for basic seeds and of $10 \%$ for certified seeds should be adopted. It is worth mentioning that this study was carried out more than one decade ago. Currently, for wheat and other crops, the tolerance standards or limits of this pathogen in the field and in the seeds are not present in the current legislation.

Based on this, this study aimed at evaluating blast damages on the productivity and quality of wheat seed as a function of different doses of initial inoculum in the field.

\section{Material and Methods}

The isolate of Pyricularia oryzae came from seeds of a wheat lot of the MGS Brilhante cultivar, produced in the municipality of Campos Altos, MG, Brazil. After the isolation from the seed, the fungus was placed in a PDA (potato, dextrose and agar) growth medium and maintained under a $12 \mathrm{~h}$ photoperiod of fluorescent light at $26^{\circ} \mathrm{C}$. After obtaining the pure colony, a transplanting in oatmeal medium $(60$ $\mathrm{g}$ of oatmeal, $12 \mathrm{~g}$ of agar in $1 \mathrm{~L}$ of water) was performed to provide better sporulation. The dishes were held at that temperature under ambient light regime for ten days. After this period, the superficial mycelium was removed and placed under constant fluorescent light at room temperature for four days to sporulate (Urashima et al., 2004). The isolate was inoculated in wheat seedlings to prove the pathogenicity, according to Koch's postulates.

From the dishes that had sporulation of the fungus, the conidia were collected by adding distilled water to the dishes and the suspension was filtered with gauze. The obtained suspension was calibrated through a hematocitometer under optical microscope, having a concentration of $1.5 \times 10^{5}$ spores. $\mathrm{mL}^{-1}$ plus Tween $20(0.01 \%)$ as a spreader.

The field experiment was carried out in Viçosa, MG, Brazil, at a location of $20^{\circ} 45^{\prime} \mathrm{LS}, 42^{\circ} 51^{\prime} \mathrm{W}$ and, at an altitude of $651 \mathrm{~m}$, in a Red-Yellow Argisol. The climate type is CWA, and the average relative humidity is $80 \%$. The experimental area had no history of blast on previous wheat crops and on existing weeds.

The soil was prepared by means of a plowing and two harrowings. The fertilization of planting consists of the application of $250 \mathrm{~kg} \cdot \mathrm{ha}^{-1}$ of the formula $08-28-16$ (NPK) in the sowing furrow and of $250 \mathrm{~kg} \cdot \mathrm{ha}^{-1}$ of ammonium sulfate as the source of $\mathrm{N}$ in coverage, in the beginning of the tillering. For control of weeds, the active ingredient Metsulfuron methyil $\left(\right.$ Ally ${ }^{\circledR}$ ) was applied 15 days after the sowing at a dose of $5 \mathrm{~g}$. $\mathrm{ha}^{-1}$ of the commercial product. The cultivation was conducted under a conventional sprinkler irrigation system and the irrigation schedule was established according to the stage of development of the plants and the level of soil moisture.

The sowing was performed after the soil preparation, at a time appropriate for the cultivation of wheat in the region (first half of May 2012), at $19.5^{\circ} \mathrm{C}$ and $83 \%$ relative humidity. The calculation of the sowing rate was conditioned to the seed weight, germination and seed quantity per meter of furrow, in order to obtain 350 seedlings per square meter.

Four wheat genotypes were used with the following blast resistance reactions: BRS 264 (susceptible control); CD 116 (moderately resistant control); VI 98053 and CD 104 (without information on resistance to blast in the state of Minas Gerais, Brazil).

The experimental design was a randomized block design, 
with three replications per treatment, totaling 60 lots. Each lot was composed of five lines of $5.0 \mathrm{~m}$ in length, with the lines being separated by $0.20 \mathrm{~m}$. Among the lots in the same block the distance of $1.5 \mathrm{~m}$ was obeyed. For the purposes of useful area, the three central lines of the lot were considered, disregarding $30 \mathrm{~cm}$ at each end of the line.

The treatments were arranged in a $4 \times 5$ factorial scheme, i.e., inoculations in four wheat genotypes (BRS 264, VI 98053, CD 116 and CD 104) and five inoculum doses of P. oryzae (inoculation of $0,5,10,20$ and $30 \%$ of plants of the experimental unit). The zero dose (without inoculation) corresponded to the application of water, then the chemical control based on pyraclostrobin + epoxiconazole (Opera $\left.{ }^{\circledR}\right)$ was carried out.

The inoculations started when the plants entered the stage of completely emerged spikes, which corresponds to stages 58-60 of (Zadoks et al.,1974) scale. Before inoculation, the plants were submitted to leaf and spike wetting by means of sprinkler irrigation for ten minutes. Due to differences in the genotype cycle, the inoculation was performed in echelon form. In order to obtain $0,5,10,20$ and $30 \%$ of plants inoculated in the experimental unit, they received 0 ; $0.20 ; 0.35 ; 0.70$ and $1 \mathrm{~L}$, respectively, of fungal suspension, applied by means of a $2 \mathrm{~L}$ sprayer with a pressure of 3.0 bar (43.5 psi), homogeneously, and the next day, moistened with water again. The application/inoculation schedule was always from 17 o'clock on, under similar conditions of temperature and relative humidity, without precipitation at the time of inoculation. The temperature and relative humidity conditions after the inoculation were recorded (Figure 1).

The final and representative incidence of blast was quantified 50 days after the inoculation of each genotype (last evaluation because it was close to the period of seed maturation), by counting the number of plants with signs or symptoms of $P$. oryzae.

The harvest was manual and performed according to the maturation of each genotype. The plants of the useful area were harvested close to the soil, collected and stored in a controlled environment. The plants with measured spikes were removed from the homogenized composite sample of each treatment and block (replication). These were husked in experimental thresher, with manual cleaning, aided by sieves for the removal of impurities. The drying of the cleaned seeds was performed at room temperature at approximately $13 \%$ humidity, after which they were packed in Kraft paper and stored at low temperature and humidity. Once the productivities were recorded, average seed samples were separated and sent to the seed analysis laboratory. The working sample and the seeds homogenization were performed with the aid of a sample divider. The following determinations were made:

Mass of 100 plants - by weighing 100 plants mown close to the ground; and Seed mass of 100 spikes - determined by weighing seeds obtained from 100 spikes.

Seed productivity - quantified by weighing the total of seeds of each lot and converted to $\mathrm{kg}$. ha- ${ }^{-1}$.

Germination -four replications of 50 seeds were used, distributed on rolls of "germitest" paper, at $20^{\circ} \mathrm{C}$. The volume of water for imbibition was 2.5 times the mass of the substrate. The evaluations were performed four (first count) and eight days (final count) after assembling the test, according to the Rules for Seed Testing (Brasil, 2009).

First germination count (FGC) - the percentage of normal seedlings was recorded at the first germination test count.

Germination speed index (GSI) -conducted concomitantly to the germination test, determined by daily evaluations up to the fifteenth day after sowing. The GSI was calculated according to the formula of Maguire (1962), according to Nakagawa (1999).

Dry matter mass of the seedlings - obtained from four replications of 20 seeds distributed on three sheets of germitest paper, moistened with distilled water in the ratio of 2.5 times their weight, placed under the same conditions used in the germination test. The mass was determined after the caryopsis removal and oven drying at $70{ }^{\circ} \mathrm{C}$ for 24 hours and subsequent weighing of the normal seedlings found in the germination test (adapted from Nakagawa, 1999).

Hectolitric weight of the seeds - determined on a specific

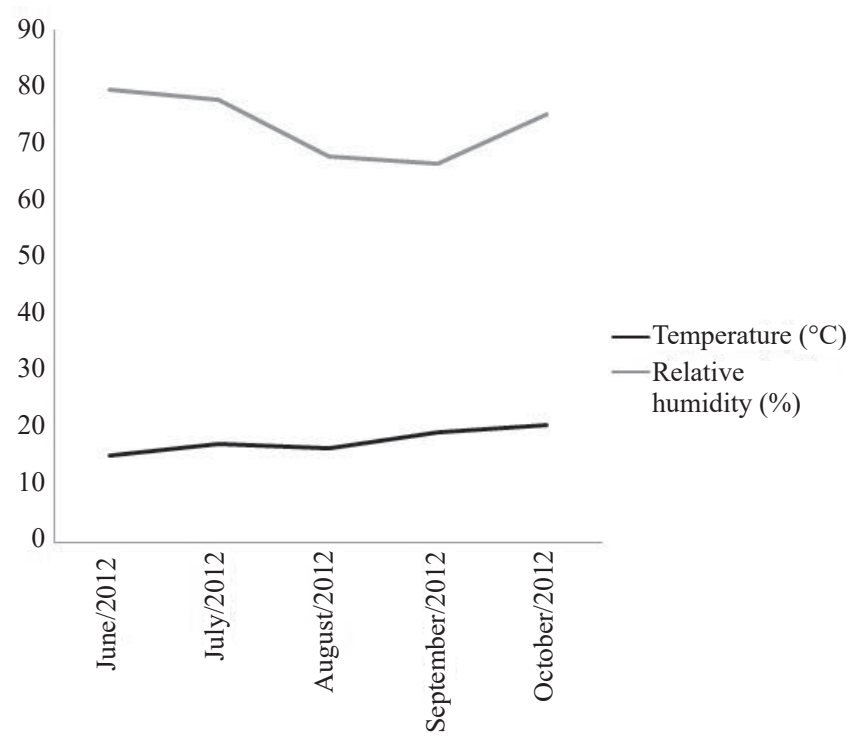

Figure 1. Climatic conditions after the inoculation of the genotypes BRS 264, VI 98053, CD 116 and CD 104 during the test in Viçosa-MG, Brazil. 
scale of the Dalle Molle brand, using the methodology proposed for the Rule for Seed Testing (Brasil, 2009).

Incidence of P. oryzae in the seeds - using the modified filter paper method, with freezing, according to Machado (1988), with four replications of 50 seeds. Three sheets of filter paper were distributed on plastic "gerbox" plates and moistened with distilled water. The plates were maintained in an incubation chamber at $25{ }^{\circ} \mathrm{C}$, with photoperiod of $12 \mathrm{~h}$. After 24 hours, the plates were transferred to a freezer at $-20{ }^{\circ} \mathrm{C}$ for 24 hours. Subsequently, they were again maintained in the incubation chamber under the above described conditions for seven days. The evaluations were performed by examining the seeds using a stereoscopic and optical microscope, and the percentage of seeds with Pyricularia oryzae was recorded.

Regression analysis were performed with the aid of the SAS ${ }^{\circledR}$ software (Statistical Analysis System, version 9.2) for the incidence data of P. oryzae in the plants. When necessary, the percentage results were transformed through the arcsin function $(\mathrm{x} / 100)^{1 / 2}$ and submitted to the ANOVA by the $\mathrm{F}$ test, and the means were compared by the Tukey test at a 5\% probability level. Correlation analyses (r) were performed with the aid of the $\mathrm{SAS} \otimes$ software for the following characteristics: blast incidence in the plants, incidence of $P$. oryzae in the harvested seeds, severity in the spikes, germination, hectolitric weight and seed productivity.

\section{Results and Discussion}

High incidence of blast in the field occurred in all genotypes, obtained after the inoculation with the initial inoculum doses of P. oryzae (Figure 2). Higher incidences were observed when the highest doses of inoculum were applied (20 and 30\%). At the lowest inoculum dose (5\%), for genotypes VI 98053 and CD 104, incidences above 50\% were obtained. These data are important for the cultivation and breeding programs of these genotypes, since they do not have information about the resistance to blast in the region. They are also of great concern due to the strict disease control requirements for the seed production fields.

For the mass of 100 plants and the seed mass of 100 spikes there were no differences among the treatments.

The seed productivity reduced significantly for the cultivars BRS 264 and CD 104, from 10\% of inoculated plants (Table 1). In the genotypes VI 98053 and CD 116 there was a significant reduction in the dose of $20 \%$ of initial inoculum. When comparing the values observed in the control treatments $(0 \%$ inoculation + fungicide) with the values of productivity found in the $20 \%$ inoculum dose (low productivities), the respective losses were observed: 1.577 $\mathrm{kg} \cdot \mathrm{ha}^{-1}(42 \%)$ for the cultivar BRS 264; $526 \mathrm{~kg} \cdot \mathrm{ha}^{-1}(19 \%)$ for the lineage VI $98053 ; 1.331 \mathrm{~kg} \cdot \mathrm{ha}^{-1}(34 \%)$ for the cultivar CD 116; and $1.192 \mathrm{~kg} \cdot \mathrm{ha}^{-1}(35 \%)$ for the cultivar CD 104. This reflects the damage that blast can cause when there is a high incidence of the disease.

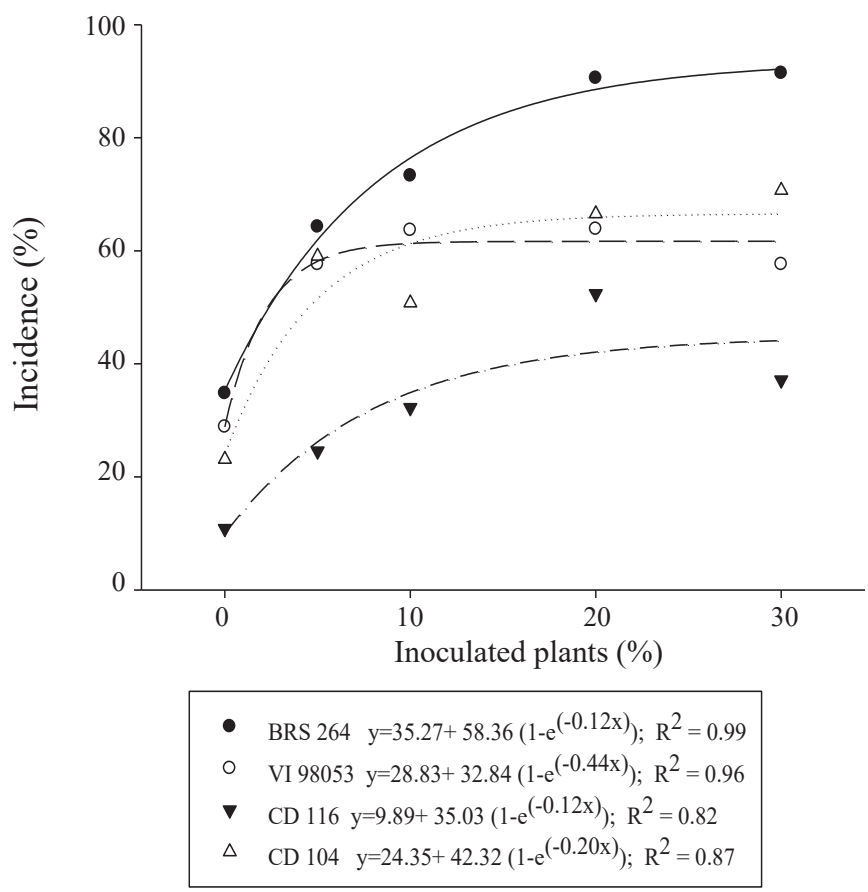

Figure 2. Incidence of blast on wheat genotypes as a function of the initial inoculum dose of P. oryzae in the plants.

Table 1. Productivity of seeds $\left(\mathrm{kg} \cdot \mathrm{ha}^{-1}\right)$ harvested from wheat genotypes as a function of the initial inoculum dose of $P$. oryzae in the field.

\begin{tabular}{clllc}
\hline \multirow{2}{*}{ Inoculated plants (\%) } & \multicolumn{4}{c}{ Genotypes } \\
\cline { 2 - 5 } & BRS 264 & VI 98053 & CD 116 & CD 104 \\
\hline 0 & $3.733 .3 \mathrm{aA}$ & $2.738 .2 \mathrm{abB}$ & $3.952 .1 \mathrm{aA}$ & $3.371 .0 \mathrm{aAB}$ \\
5 & $3.639 .2 \mathrm{aA}$ & $2.975 .2 \mathrm{aA}$ & $3.578 .6 \mathrm{aA}$ & $3.328 .4 \mathrm{aA}$ \\
10 & $2.789 .6 \mathrm{bAB}$ & $2.785 .6 \mathrm{abB}$ & $3.464 .8 \mathrm{aA}$ & $2.164 .6 \mathrm{bB}$ \\
20 & $2.155 .5 \mathrm{bA}$ & $2.212 .7 \mathrm{bA}$ & $2.621 .5 \mathrm{bA}$ & $2.178 .6 \mathrm{bA}$ \\
30 & $2.184 .0 \mathrm{bB}$ & $2.373 .9 \mathrm{abB}$ & $3.331 .6 \mathrm{abA}$ & $2.147 .8 \mathrm{bB}$ \\
\hline
\end{tabular}

Means followed by the same lowercase letter in vertical or upper case in horizontal do not differ among themselves at a $5 \%$ probability by the Tukey test. 
In Dourados-MS, Brazil, in an area with natural presence of P. oryzae, there was variation of the wheat productivity caused by blast, according to the tested genotypes, with an average loss of 12\% (Goulart et al., 2007). Nevertheless, Urashima et al. (2009) reported that the incidence of the disease in the cultivar CD 104 did not result in a significant reduction of the productivity in the state of São Paulo, Brazil. The different responses must be associated to the different environmental conditions, mainly temperature and humidity, found in the different cultivation regions; to the differentiated levels of resistance of the genotypes; to the absence of control measures or the type of control employed, in the case of being chemical, still with low efficiency.

In the genotypes BRS 264, VI 98053 and CD 104, the germination was reduced, especially when harvested from treatments with 20 or $30 \%$ of initial inoculum (Table 2). Genotypes collected from the control treatments and the treatments with 5 and $10 \%$ of inoculum presented germination within the standard of production and commercialization of wheat seeds in Brazil, which is $70 \%$ for the basic seed category and $80 \%$ for the categories C1, C2, S1 and S2 (Brasil, 2013).

In the cultivar CD 104, the presence of the fungus significantly reduced the germination, according to the differences observed between the control dose $(0 \%$ +fungicide $)$ and the other doses of inoculum of the pathogen (Table 2). The cultivar CD 116 showed satisfactory germination (above 70\%), except at the dose of $20 \%$ of inoculum. The moderate resistance to blast may have positively influenced the seed germination of this cultivar, due to lower incidences of the disease in the field compared to the other genotypes (Figure 2). The genotypes VI 98053 and CD 104, which do not have information about the resistance to blast in the region, presented lower germination, however, within standard, when the doses of 5 and $10 \%$ of initial inoculum were used.

Urashima et al. (2009) also observed low germination (38\%) of wheat seeds of the cultivar CD 104, which were associated with $P$. oryzae. These authors raise the hypothesis of the moment of infection of $P$. oryzae, since the presence of the fungus in the last stages of seed formation has a significant effect on germination, i.e., it can be affected because the pathogen may infect the tissues of the embryonic axis. According to Kobayasti and Pires (2011), the activity of pathogens acts as a reduction factor in the physiological performance of wheat seeds.

For the FGC, the same responses to the germination test were observed, i.e., a considerable reduction of normal seedlings from seeds harvested from the treatments with inoculations of 20 or $30 \%$ of plants, mainly (Table 3 ). This indicates a reduction in the vigor through this test, especially when the highest doses of inoculum are used in the field.

The vigor, analyzed by the germination speed index (GSI), was reduced for most of the treatments inoculated with the fungus, with differences starting from the lowest dose of initial inoculum (5\%) (Table 4). Therefore, through this test, there was again the deleterious effect of the pathogen on the vigor of the seeds. Faiad et al. (1994), working with rice seeds, found that seeds infected with $P$. oryzae had a reduction in the emergence speed index.

Table 2. Germination (\%) of seeds harvested from wheat genotypes as a function of the initial inoculum dose of P. oryzae in the field.

\begin{tabular}{ccccc}
\hline Inoculated & \multicolumn{4}{c}{ Genotypes } \\
\cline { 2 - 5 } $\begin{array}{c}\text { plants } \\
(\%)\end{array}$ & BRS 264 & VI 98053 & CD 116 & CD 104 \\
\hline 0 & $74 \mathrm{bB}^{1}$ & $81 \mathrm{aAB}$ & $81 \mathrm{bAB}$ & $89 \mathrm{aA}$ \\
5 & $90 \mathrm{aA}$ & $79 \mathrm{abB}$ & $91 \mathrm{aA}$ & $76 \mathrm{bB}$ \\
10 & $80 \mathrm{bB}$ & $69 \mathrm{bC}$ & $90 \mathrm{aA}$ & $72 \mathrm{bBC}$ \\
20 & $22 \mathrm{cB}$ & $66 \mathrm{bA}$ & $53 \mathrm{cA}$ & $6 \mathrm{cB}$ \\
30 & $16 \mathrm{cC}$ & $44 \mathrm{cB}$ & $74 \mathrm{bA}$ & $7 \mathrm{cC}$ \\
\hline
\end{tabular}

${ }^{1}$ Based on the $\arcsin (\mathrm{x} / 100)^{1 / 2}$ transformation; Means followed by the same lowercase letter in vertical or upper case in horizontal do not differ among themselves at a $5 \%$ probability by the Tukey test.

Table 3. First germination count ( $\%$ FGC) of seeds harvested from wheat genotypes as a function of the initial inoculum dose of $P$. oryzae in the field.

\begin{tabular}{ccccc}
\hline Inoculated & \multicolumn{4}{c}{ Genotypes } \\
\cline { 2 - 5 } $\begin{array}{c}\text { Plants } \\
(\%)\end{array}$ & BRS 264 & VI 98053 & CD 116 & CD 104 \\
\hline 0 & $73 \mathrm{bB}^{1}$ & $80 \mathrm{aB}$ & $81 \mathrm{bAB}$ & $89 \mathrm{aA}$ \\
5 & $90 \mathrm{aA}$ & $75 \mathrm{abB}$ & $91 \mathrm{aA}$ & $76 \mathrm{bB}$ \\
10 & $80 \mathrm{bB}$ & $67 \mathrm{bC}$ & $89 \mathrm{abA}$ & $70 \mathrm{bC}$ \\
20 & $11 \mathrm{cB}$ & $33 \mathrm{cA}$ & $37 \mathrm{dA}$ & $3 \mathrm{cB}$ \\
30 & $2.0 \mathrm{cB}$ & $9.0 \mathrm{~dB}$ & $70 \mathrm{cA}$ & $1 \mathrm{cB}$ \\
\hline
\end{tabular}

${ }^{1}$ Based on the $\arcsin (x / 100)^{1 / 2}$ transformation; Means followed by the same lowercase letter in vertical or upper case in horizontal do not differ among themselves at a $5 \%$ probability by the Tukey test.

Table 4. Germination speed index (GSI) of seeds harvested from wheat genotypes as a function of the initial inoculum dose of P. oryzae in the field.

\begin{tabular}{ccclc}
\hline Inoculated & \multicolumn{4}{c}{ Genotypes } \\
\cline { 2 - 5 } $\begin{array}{c}\text { Plants } \\
(\%)\end{array}$ & BRS 264 & VI 98053 & CD 116 & CD 104 \\
\hline 0 & $11.19 \mathrm{aA}$ & $10.21 \mathrm{aAB}$ & $9.66 \mathrm{aB}$ & $8.82 \mathrm{aB}$ \\
5 & $4.75 \mathrm{bB}$ & $5.77 \mathrm{cB}$ & $8.64 \mathrm{abA}$ & $5.24 \mathrm{bB}$ \\
10 & $3.26 \mathrm{cB}$ & $8.93 \mathrm{abA}$ & $7.88 \mathrm{bA}$ & $3.05 \mathrm{cB}$ \\
20 & $5.60 \mathrm{bB}$ & $8.43 \mathrm{bA}$ & $6.30 \mathrm{cB}$ & $2.22 \mathrm{cC}$ \\
30 & $0.51 \mathrm{dC}$ & $6.69 \mathrm{cB}$ & $8.73 \mathrm{abA}$ & $0.43 \mathrm{dC}$ \\
\hline
\end{tabular}

Means followed by the same lowercase letter in vertical or upper case in horizontal do not differ among themselves at a $5 \%$ probability by the Tukey test. 
Only the genotype CD 116 presented differences for the dry mass of seedlings, with reduction, when used the inoculation of $20 \%$ of the plants (Table 5). For the BRS 264, differences were also observed, however, inconsistent.

For the hectolitric weight of the seeds, the majority of the treatments did not present differences as a function of the initial inoculum doses of the fungus, except for the genotypes BRS 264 and CD 104, which had the lowest values at the doses of 20 and 30\% of inoculum in the field (Table 6). Goulart (2004) also observed a reduction in the seed hectolitric weight after the infection of spikes by P. oryzae.

For the incidence of $P$. oryzae in the seeds, incidences ranging from 0 to $30 \%$ among the treatments were recorded (Table 7). It was observed, through this evaluation, that there was the transmission of the pathogen present in the field to the wheat seeds, in all the genotypes.

It was observed that the lowest inoculum dose (5\%) was able to cause the lowest incidence (8\%) in the seeds of the cultivar BRS 264; nonetheless, this dose caused the highest incidence (30\%) in the seeds of the cultivar CD 104 (Table 7). In this last cultivar, the highest dose of initial inoculum (30\%) also provided the highest recorded incidence (30\%), and in the lineage VI 98053 this dose caused half of this incidence (15\%). These results suggest that different doses of initial inoculum in the field can cause variable incidences in the harvested seeds.

Even with a high incidence of the pathogen in the seeds, the appearance of symptoms in the seedlings may be low and vice-versa, and there is no direct relationship among the incidence in the plant and the incidence in the seeds, and the transmissibility (Faiad et al., 1994). Asymptomatic seeds were observed, even with the application of treatments that generated high incidences of the disease in the field. Apparently healthy seeds harvested from areas with blast are able to present internal mycelium, and this may not be detected in the sanity analysis. This contributes to the dispersion of the pathogen by the commercialization of "erroneously" approved lots. In this situation is the importance of the sensitivity of the employed test and the ideal conditions for it.

Near the harvest, the control treatments probably lost the residual effect of the fungicide by the date of the last application, and this, conjunctly with the action of dissemination of the conidia by the wind, implied in the increase of the incidence; therefore, they presented similar results to the ones of the inoculated treatments (Table 7). This corroborates Urashima's et al. (2009) study, who observed a high incidence of $P$. oryzae in the seeds of the cultivar CD 104, with no differences between the control (with $69 \%$ incidence in spike seeds without symptoms) and the treatment with seeds harvested from spikes with symptoms (incidence of $72 \%$ ).
According to Machado (1994), lots with incidences of P. oryzae above $10 \%$ for certified wheat seeds should not be commercialized, which would "condemn" some genotypes studied here, considering the majority of the inoculum doses of the present study. Silva et al. (2009) state that in cases of high incidences (these had a $26.7 \%$ incidence rate), lots of wheat should be used as grains, being commercialized to

Table 5. Dry matter mass of seedlings (mg.seedling ${ }^{-1}$ ) from wheat genotype seeds as a function of the initial inoculum dose of $P$. oryzae in the field.

\begin{tabular}{ccccc}
\hline Inoculated & \multicolumn{4}{c}{ Genotypes } \\
\cline { 2 - 5 } $\begin{array}{c}\text { plants } \\
(\%)\end{array}$ & BRS 264 & VI 98053 & CD 116 & CD 104 \\
\hline 0 & $9.84 \mathrm{abA}$ & $9.00 \mathrm{aA}$ & $9.91 \mathrm{aA}$ & $9.34 \mathrm{aA}$ \\
5 & $9.88 \mathrm{abA}$ & $8.65 \mathrm{aA}$ & $9.41 \mathrm{aA}$ & $10.26 \mathrm{aA}$ \\
10 & $11.16 \mathrm{aA}$ & $9.69 \mathrm{aAB}$ & $7.25 \mathrm{aB}$ & $8.69 \mathrm{aAB}$ \\
20 & $7.56 \mathrm{bA}$ & $9.70 \mathrm{aA}$ & $3.00 \mathrm{bB}$ & $7.81 \mathrm{aA}$ \\
30 & $9.00 \mathrm{abA}$ & $11.55 \mathrm{aA}$ & $9.03 \mathrm{aA}$ & $8.67 \mathrm{aA}$ \\
\hline
\end{tabular}

Means followed by the same lowercase letter in vertical or upper case in horizontal do not differ among themselves at a $5 \%$ probability by the Tukey test.

Table 6. Hectolitric weight $\left(\mathrm{kg} \cdot \mathrm{hL}^{-1}\right)$ of seeds harvested from wheat genotypes as a function of the initial inoculum dose of $P$. oryzae in the field.

\begin{tabular}{cllll}
\hline Inoculated & \multicolumn{4}{c}{ Genotypes } \\
\cline { 2 - 5 } $\begin{array}{c}\text { plants } \\
(\%)\end{array}$ & BRS 264 & VI 98053 & CD 116 & CD 104 \\
\hline 0 & $80.6 \mathrm{aA}$ & $83.1 \mathrm{aA}$ & $77.7 \mathrm{aA}$ & $80.1 \mathrm{aA}$ \\
5 & $81.0 \mathrm{aA}$ & $81.0 \mathrm{aA}$ & $70.9 \mathrm{aB}$ & $78.6 \mathrm{abAB}$ \\
10 & $75.6 \mathrm{abAB}$ & $83.1 \mathrm{aA}$ & $77.7 \mathrm{aAB}$ & $71.65 \mathrm{abB}$ \\
20 & $68.2 \mathrm{bA}$ & $73.6 \mathrm{aA}$ & $72.7 \mathrm{aA}$ & $69.85 \mathrm{bA}$ \\
30 & $68.2 \mathrm{bA}$ & $73.8 \mathrm{aA}$ & $73.4 \mathrm{aA}$ & $68.95 \mathrm{bA}$ \\
\hline
\end{tabular}

Means followed by the same lowercase letter in vertical or upper case in horizontal do not differ among themselves at a $5 \%$ probability by the Tukey test.

Table 7. Incidence (\%) of Pyricularia oryzae in seeds harvested from wheat genotypes as a function of initial inoculum dose of the fungus in the field.

\begin{tabular}{ccrrc}
\hline Inoculated & \multicolumn{4}{c}{ Genotypes } \\
\cline { 2 - 5 } $\begin{array}{c}\text { plants } \\
(\%)\end{array}$ & BRS 264 & VI 98053 & CD 116 & CD 104 \\
\hline 0 & $10.0 \mathrm{bcA}^{1}$ & $4.0 \mathrm{bA}$ & $0.0 \mathrm{aA}$ & $8.0 \mathrm{bA}$ \\
5 & $8.0 \mathrm{cB}$ & $24.0 \mathrm{aA}$ & $11.0 \mathrm{aB}$ & $30.0 \mathrm{aA}$ \\
10 & $24.0 \mathrm{aA}$ & $27.0 \mathrm{aA}$ & $8.0 \mathrm{aB}$ & $24.0 \mathrm{aA}$ \\
20 & $13.0 \mathrm{abcAB}$ & $24.0 \mathrm{aA}$ & $11.0 \mathrm{aB}$ & $18.0 \mathrm{abAB}$ \\
30 & $21.0 \mathrm{abAB}$ & $15.0 \mathrm{abB}$ & $12.0 \mathrm{aB}$ & $30.0 \mathrm{aA}$ \\
\hline
\end{tabular}

${ }^{1}$ Based on the $\arcsin (\mathrm{x} / 100)^{1 / 2}$ transformation; Means followed by the same lowercase letter in vertical or upper case in horizontal do not differ among themselves at a $5 \%$ probability by the Tukey test. 
mills, and not as seeds.

The cultivars BRS 264 and CD 104 presented significant negative correlations among the incidence of the pathogen in the plants and the parameters of germination, hectolitric weight and productivity; and between the incidence of P. oryzae on harvested seeds and the productivity, for the cultivar BRS 264 (Table 8). Coelho et al. (2016) corroborate this data, for they observed a positive correlation between losses in productivity and blast. Thus, these data indicate that in seed production fields of these genotypes the increase in the incidence of $P$. oryzae in the plants may imply both low productivity and low physiological quality of the seeds.

In general, in relation to the physiological quality, some of the lower values of germination and of vigor were found, mainly in the doses of 20 or $30 \%$ of initial inoculum, especially for the genotypes BRS 264 and CD 104. These low values may have been a consequence of the direct and indirect damages caused by P. oryzae in the mother plant and in the seed. Researchers report that this pathogen does not significantly interfere with wheat germination (Urashima et al., 2009), and this fact was observed in the absence of correlation between the incidence of $P$. oryzae in the harvested seed and the germination (Table 8). Nevertheless, the reduction in the germination and in the vigor may be associated with the fact that the pathogen, when colonizing the plant, considerably reduces the transport of photosynthates to the seed filling during the booting stage, causing a decrease in reserves such as carbohydrates, lipids and proteins necessary for the metabolism and nutrition of the embryo, possibly generating seeds and/or plants with little vigor.

Therefore, $P$. oryzae may act significantly in the field stage, in the development of the plant, reducing the transport of assimilates to the formation of the seeds, and consequently diminishing their physiological potential, which clarifies the correlation between the incidence of the disease in the field and the germination for some genotypes (Table 8). It is worth noting that, once the transmissibility (incidence in the harvested seed) has been verified, the pathogen mayor may not affect the germination.

Only in the lineage VI 98053 the positive and significant correlation between the incidence of the pathogen in the plant and the incidence of the pathogen in the harvested seed was observed, i.e., a direct relation between the presence of blast in the field and its transmission to the wheat seed (Table 8). This datum is of extreme importance, since this genotype, besides not having information in the region of Minas Gerais, Brazil, regarding blast, also has no information regarding the transmission of the pathogen by the seed, as well as for the

Table 8. Pearson correlation coefficients obtained between the characteristics of reaction to blast in the field and the laboratory seed quality tests in wheat genotypes.

\begin{tabular}{|c|c|c|c|c|c|}
\hline Genotype & & Germination & $\begin{array}{l}\text { Incidence of } P \text {. oryzae } \\
\text { in the harvested seed }\end{array}$ & $\begin{array}{l}\text { Hectolitric weight of } \\
\text { seeds }\end{array}$ & Productivity \\
\hline \multirow{3}{*}{ BRS 264} & $\begin{array}{l}\text { Incidence of } P \text {. oryzae in the } \\
\text { plant }\end{array}$ & $-0.81^{*}$ & $0.51^{\mathrm{ns}}$ & $-0.87^{*}$ & $-0.85^{*}$ \\
\hline & Severity in the spike ${ }^{1}$ & $-0.35^{\text {ns }}$ & $-0.15^{\mathrm{ns}}$ & $-0.39^{\text {ns }}$ & $-0.30^{\mathrm{ns}}$ \\
\hline & $\begin{array}{l}\text { Incidence of } P \text {. oryzae in the } \\
\text { harvested seed }\end{array}$ & $0.40^{\mathrm{ns}}$ & - & $-0.51^{\mathrm{ns}}$ & $-0.82 *$ \\
\hline \multirow{3}{*}{ VI 98053} & $\begin{array}{l}\text { Incidence of } P \text {. oryzae in the } \\
\text { plant }\end{array}$ & $-0.44^{\mathrm{ns}}$ & $0.92 *$ & $-0.45^{\mathrm{ns}}$ & $-0.27^{\mathrm{ns}}$ \\
\hline & Severity in the spike ${ }^{1}$ & $-0.46^{\text {ns }}$ & $-0.08^{\mathrm{ns}}$ & $0.15^{\mathrm{ns}}$ & $0.34^{\mathrm{ns}}$ \\
\hline & $\begin{array}{l}\text { Incidence of } P \text {. oryzae in the } \\
\text { harvested seed }\end{array}$ & $0.29^{\mathrm{ns}}$ & - & $-0.13^{\mathrm{ns}}$ & $0.02^{\mathrm{ns}}$ \\
\hline \multirow{3}{*}{ CD 116} & $\begin{array}{l}\text { Incidence of } P \text {. oryzae in the } \\
\text { plant }\end{array}$ & $-0.72^{\text {ns }}$ & $0.75^{\mathrm{ns}}$ & $0.16^{\mathrm{ns}}$ & $-0.72^{\mathrm{ns}}$ \\
\hline & Severity in the spike ${ }^{1}$ & $-0.16^{\mathrm{ns}}$ & $0.45^{\text {ns }}$ & $0.12^{\text {ns }}$ & $-0.51^{\mathrm{ns}}$ \\
\hline & $\begin{array}{l}\text { Incidence of } P \text {. oryzae in the } \\
\text { harvested seed }\end{array}$ & $-0.43^{\text {ns }}$ & - & $0.09^{\mathrm{ns}}$ & $-0.45^{\text {ns }}$ \\
\hline \multirow{3}{*}{ CD104 } & $\begin{array}{l}\text { Incidence of } P \text {. oryzae in the } \\
\text { plant }\end{array}$ & $-0.86 *$ & $0.68^{\mathrm{ns}}$ & $-0.86^{*}$ & $-0.87 *$ \\
\hline & Severity in the spike ${ }^{1}$ & $-0.53^{\text {ns }}$ & $0.84 *$ & $-0.66^{\mathrm{ns}}$ & $-0.61^{\mathrm{ns}}$ \\
\hline & $\begin{array}{l}\text { Incidence of } P \text {. oryzae in the } \\
\text { harvested seed }\end{array}$ & $-0.11^{\mathrm{ns}}$ & - & $-0.40^{\mathrm{ns}}$ & $-0.32^{\mathrm{ns}}$ \\
\hline
\end{tabular}

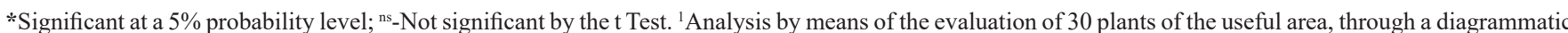
scale for the quantification of the symptoms of blast on the spike. 
cultivar CD 104. Goulart et al. (1995) corroborate this datum when they observed a direct correlation between the presence of blast on wheat spikes in the field and the percentage of harvested seeds with the presence of P. oryzae.

Studies that correlate the presence of the disease in the field and the incidence of the pathogen in the seeds for the determination of tolerance standards in seed production fields are of great utility (Cornélio et al., 2000), the present study being an example of this. Thus, among the most important practices for the production of seeds with high sanitary and physiological quality are the periodic phytosanitary inspections, which aim to reduce or even eliminate the initial inoculum.

\section{Conclusions}

There is a reduction in the productivity and in the physiological quality of wheat seeds of the genotypes BRS 264, VI 98053, CD 116 and CD 104, as a function of the concentration of the initial inoculum of $P$. oryzae applied in the field plants, mainly in doses of 20 or $30 \%$ of inoculum.

In the evaluated genotypes, the incidence of blast in the field is capable of causing the transmission of P. oryzae from the mother plant to the wheat seeds.

For the genotypes BRS 264, VI 98053, CD 116 and CD 104 , it is recommended not to use as seeds the ones coming from production fields with incidence of blast from $20 \%$ on the plants, when evaluated near the period of seed maturation. Incidences below 20\% need to be studied for the exact indication of P. oryzae tolerance standards in the field.

\section{Acknowledgments}

To the FAPEMIG (Research Support Foundation of Minas Gerais) for its financial support.

To Mr. Cupertino, laboratory technician of the UFV, for the aid in the preparation of the fungal suspension.

\section{References}

BRASIL. Ministério da Agricultura, Pecuária e Abastecimento. Regras para análise de sementes. Ministério da Agricultura, Pecuária e Abastecimento. Secretaria de Defesa Agropecuária. Brasília, DF: MAPA/ACS, 2009. 395p. http://www.agricultura.gov.br/arq_editor/ file/2946_regras_analise_sementes.pdf

BRASIL. Instrução Normativa $n .{ }^{\circ} 45$, de 17 de setembro de 2013. Padrões de identidade e qualidade para a produção e a comercialização de sementes. Anexo XXVII - Padrões para produção e comercialização de sementes de trigo. Diário Oficial da União, Brasília, DF, 18 Set. 2013. Seção1, p.20 Brasília, DF. http://apasem. com.br/site/wp-content/uploads/padroesin0452013.pdf
CARGNIN, A.; SOUZA, M.A.; FRONZA, V.; FOGAÇA, C.M. Genetic and environmental contributions to increased wheat yield in Minas Gerais, Brazil. Scientia Agricola, v.66, n.3, p. 317-322, 2009. http://www.scielo.br/scielo.php?script=sci arttext\&pid=S0103-90162009000300006

COELHO, M.A.O.; TORRES, G.A.M.; CECON, P.R.; SANTANA, F.M. Sowing date reduces the incidence of wheat blast disease. Pesquisa Agropecuária Brasileira, v.51, n.5, p.631-637, 2016. http:// www.scielo.br/pdf/pab/v51n5/1678-3921-pab-51-05-00631.pdf

CORNÉLIO, V.O.; SANTOS, P.; SOARES, A.; LOPES, T. Associação entre a incidência de brusone e a presença de Pyricularia grisea nas sementes de arroz. Pesquisa Agropecuária Brasileira, v.35, n.3, p.639-645, 2000. http://www.scielo.br/scielo.php?script=sci arttext\&pid=S0100-204X2000000300021

CRUZ, M.F.A.; PRESTES, A.M.; MACIEL, J.L.N.; SCHEEREN, P.L. Resistência parcial à brusone de genótipos de trigo comum e sintético nos estádios de planta jovem e de planta adulta. Tropical Plant Pathology, v.35, n.1, p.24-31, 2010. http://www.scielo.br/ scielo.php?script $=$ sci_arttext\&pid $=$ S198256762010000100004\&1$\mathrm{ng}=\mathrm{en} \& \mathrm{nrm}=\mathrm{iso} \& \operatorname{lng}=\mathrm{pt}$

CRUZ, M.F.A.; DINIZ, A.P.C.; RODRIGUES, F.A.; BARROS, E.G. Aplicação foliar de produtos na redução da severidade da brusone do trigo. Tropical Plant Pathology, v.36, n.6, p.424-428, 2011. http://www. scielo.br/scielo.php?script=sci_arttext\&pid=S1982-56762011000600014

DEBONA, D.; RIOS, J.A.; NASCIMENTO, K.J.T.; SILVA, L.C.; RODRIGUES, F.A. Influence of magnesium on physiological responses of wheat infected by Pyricularia oryzae. Plant Pathology, v.65, n.1, p.114-123, 2016. http://onlinelibrary.wiley.com/doi/10.1111/ ppa.12390/pdf

FAIAD, M.G.R.; MACHADO, J.C.; VIEIRA, M.G.C.; CORNELIO, V.M.O. Efeito e transmissibilidade de Pyricularia oryzae Cav. em sementes de arroz sob condições controladas. Revista Brasileira de Sementes, v.16, n.1, p.45-49, 1994. http://www.scielo.br/scielo. php?script=sci_serial\&pid $=2317-1537 \& \operatorname{lng}=$ en $\&$ nrm $=$ iso

GOULART, A.C.P.; PAIVA, F.A.; MESQUITA, A.N. Ocorrência da brusone (Pyricularia oryzae) do trigo (Triticum aestivum) em Mato Grosso do Sul. Fitopatologia Brasileira, v.15, n.1, p.112-114, 1990.

GOULART, A.C.P.; PAIVA, F.A.; MESQUITA, N. Perdas em trigo (Triticum aestivum) causadas por Pyricularia oryzae. Fitopatologia Brasileira, v. 17, p. 115-117, 1992.

GOULART, A.C.P.; PAIVA, F.A.; ANDRADE, P.J.M. Relação entre a incidência da brusone em espigas de trigo e a presença de $P$. grisea nas sementes colhidas. Fitopatologia Brasileira, v.20, n.2, p.184$189,1995$.

GOULART, A.C.P. Brusone do trigo diminui rendimento dos grãos. A Lavoura, v.107, n.650, p.18-21, 2004.

GOULART, A.C.P.; SOUSA, P.G.; URASHIMA, A.S. Danos em trigo causados pela infecção de Pyricularia grisea. Summa Phytopathologica, v.33, n.4, p.358-363, 2007. http://www.scielo.br/scielo.php?script=sci arttext\&pid=S0100-54052007000400007 
KOBAYASTI, L.; PIRES, A.P. Levantamento de fungos em sementes de trigo. Pesquisa Agropecuária Tropical, v.41, n.4, p.572578, 2011. http://www.scielo.br/pdf/pat/v41n4/a16v41n4.pdf

MACHADO, J.C. Patologia de sementes: fundamentos e aplicações. Lavras: ESAL/FAEPE, 1988. 107 p.

MACHADO, J.C. Padrões de tolerância de patógenos associados a sementes. Revisão Anual de Patologia de Plantas, v.2, p.229-263, 1994.

MACIEL, J.L.N.; DANELLI, A.L.D.; BOARETTO, C.; FORCELINI, C.A. Diagrammatic scale for the assessment of blast on wheat spikes. Summa Phytopathologica, v.39, n.3, p.162-166, 2013. http://www.scielo. br/scielo.php?script=sci_arttext\&pid=S0100-54052013000300003

MAGUIRE, J.D. Speeds of germination-aid selection and evaluation for seedling emergence and vigor. Crop Science, v.2, p. 176-177, 1962.

MEDINA, P.F.; TANAKA, M.A.S.; PARISI, J.J.D. Sobrevivência de fungos associados ao potencial fisiológico de sementes de triticale (X. triticosecale Wittmack) durante o armazenamento. Revista Brasileira de Sementes, v.31, n.4, p.17-26, 2009. http://www.scielo. br/scielo.php?script=sci_arttext\&pid=S0101-31222009000400002

NAKAGAWA, J. Testes de vigor baseados no desempenho das plântulas. IN: KRZYZANOWSKI, F.C; VIEIRA, R.D; FRANÇANETO, J.B. (Ed). Vigor de sementes: conceitos e testes. Londrina: ABRATES, 1999. 218p.

OLIVEIRA, D.M.; SOUZA, M.A.; ROCHA, V.S.; ASSIS, J.C. Desempenho de genitores e populações segregantes de trigo sob estresse de calor. Bragantia, v.70, n.1, p.25-32, 2011. http://www. scielo.br/scielo.php?pid=S0006-87052011000100005\&script $=$ sci abstract\&tlng=pt

ROCHA, J.R.A.S.C.; PIMENTEL, A.J.B.; RIBEIRO, G.; SOUZA, M.A. Eficiência de fungicidas no controle da brusone em trigo. Summa Phytopathologica, v.40, n.4, p.347-352, 2014. http://www.scielo.br/ pdf/sp/v40n4/a08v40n4.pdf

SAHARAN, M.S.; BHARDWAJ, S.C.; CHATRATH, R.; SHARMA, P.; CHOUDHARY, A.K.; GUPTA, R.K. Wheat blast disease-An overview. Journal of Wheat Research, v.8, n.1, p. 1-5, 2016. http:// epubs.icar.org.in/ejournal/index.php/JWR/article/view/60113/24724
SILVA, C.P.; NOMURA, E.; FREITAS, E.G.; BRUGNARO, C.; URASHIMA, A.S. Eficiência de tratamentos alternativos no controle de Pyricularia grisea em sementes de trigo. Tropical Plant Pathology, v. 34, n.2, p. 127-131, 2009. http://www.scielo.br/pdf/tpp/v34n2/v34n2a09.pdf

SILVA, W.L; CRUZ, M.F.A; FORTUNATO, A.A; RODRIGUES, F.A. Histochemical aspects of wheat resistance to leaf blast mediated by silicon. Scientia Agricola, v.72, n.4, p.322-327, 2015. http:// www.scielo.br/pdf/sa/v72n4/0103-9016-sa-72-4-0322.pdf

TORRES, G.A.M.; SANTANA, F.M.; FERNANDES, J.M.C.; SÓ, M.S. Doenças da espiga causam perda de rendimento em trigo nos estados do Paraná, São Paulo e Mato Grosso do Sul, em 2009. Passo Fundo: Embrapa Trigo, 2009. 10 p. (Embrapa Trigo. Comunicado técnico online, 255). http://www.cnpt.embrapa.br/biblio/co/p co255.htm. Accessed on: May. $12^{\text {th }} 2010$

URASHIMA, A.S.; LAVORENT, N.A.; GOULART, A.C.P.; MEHTA, Y.R. Resistence spectra of wheat cultivars and virulence diversity of Magnaporthe grisea isolates in Brazil. Fitopatologia Brasileira, v.29, n.5, p.511-518, 2004. http://www.scielo.br/scielo.php?script=sci_ arttext\&pid=S0100-41582004000500007

URASHIMA, A.S.; LEITE, S.F.; GALBIERI, R. Eficiência da disseminação aérea em Pyricularia grisea. Summa Phytopathologica, v.33, n.3, p.275-279, 2007.http://www.scielo.br/pdf/sp/v33n3/11.pdf

URASHIMA, A.S.; GROSSO, C.R.F.; STABILI, A.; FREITAS, E.G.; SILVA, C.P.; NETTO, D.C.S.; FRANCO, I.; MÉROLA BOTTAN, J.H. Effect of M. grisea on seed germination, yield and quality of wheat. IN: WANG, G.L.; VALENT, B. (Eds.) Advances in Genetics, Genomics and Control of Rice Blast Disease. Springer, p.267-277, 2009.

ZADOKS, J.C.; CHANG, T.T.; KONZAK, C.F. Código decimal para os estados de crescimento dos cereais. Revista de Ciências Agrárias, n.1, p. 209-218, 1974. 